OPEN ACCESS

Edited by:

Danny Jonigk,

Hannover Medical School,

Germany

Reviewed by:

Maximilian Ackermann

Universitätsmedizin der

Johannes Gutenberg-

Universität Mainz, Germany

Anne Couvelard,

APHP and University of Paris 7 ,

France

*Correspondence:

Rafia S. Al-Lamk

rsma2@hermes.cam.ac.uk

Specialty section:

This article was submitted

to Pathology,

a section of the journal

Frontiers in Medicine

Received: 19 June 2017

Accepted: 24 August 2017

Published: 11 September 2017

Citation:

Al-Lamki RS, Bradley JR and Pober JS (2017) Human Organ Culture: Updating the Approach to

Bridge the Gap from In Vitro to

In Vivo in Inflammation, Cancer, and Stem Cell Biology.

Front. Med. 4:148.

doi: 10.3389/fmed.2017.00148

\section{Human Organ Culture: Updating the Approach to Bridge the Gap from In Vitro to In Vivo in Inflammation, Cancer, and Stem Cell Biology}

\author{
Rafia S. Al-Lamki' ${ }^{1 *}$, John R. Bradley' ${ }^{1}$ and Jordan S. Pober ${ }^{2}$ \\ 'Department of Medicine, NIHR Cambridge Biomedical Research Centre, University of Cambridge, Cambridge, \\ United Kingdom, ${ }^{2}$ Department of Immunobiology, Yale University School of Medicine, New Haven, CT, United States
}

Human studies, critical for developing new diagnostics and therapeutics, are limited by ethical and logistical issues, and preclinical animal studies are often poor predictors of human responses. Standard human cell cultures can address some of these concerns but the absence of the normal tissue microenvironment can alter cellular responses. Three-dimensional cultures that position cells on synthetic matrices, or organoid or organon-a-chip cultures, in which different cell spontaneously organize contacts with other cells and natural matrix only partly overcome this limitation. Here, we review how human organ cultures (HOCs) can more faithfully preserve in vivo tissue architecture and can better represent disease-associated changes. We will specifically describe how HOCs can be combined with both traditional and more modern morphological techniques to reveal how anatomic location can alter cellular responses at a molecular level and permit comparisons among different cells and different cell types within the same tissue. Examples are provided involving use of HOCs to study inflammation, cancer, and stem cell biology.

Keywords: human, organ culture, inflammation, cancer, stem cells

\section{INTRODUCTION}

Preclinical animal studies have had only limited success in predicting human physiology, pathology, and therapeutic responses. Traditional human cell cultures, which are often used to account for species differences are also limited in their representation of in vivo responses due to lack of an appropriate microenvironmental context of the responding cell types. Newer culture approaches, such as three-dimensional (3D) cultures, organoids, or organs-on-a-chip have attempted to better replicate the tissue microenvironment, but have been only partly successful. In this review, we will illustrate how human organ cultures (HOCs) offer a simple approach that may better address these issues. To do so, we have chosen illustrative examples from the literature from the past 30 years that have been used to gain insights into inflammatory process and diseases, cancer, and stem cell biology. More recent examples have illustrated how newer morphological approaches, such as in situ proximity ligation assay, can be applied to HOCs to reveal greater details in specific biological responses.

\section{METHODOLOGY OF HOC}

\section{The Method Described Here Reflects Our Approach for Optimizing HOC}

Tissue for HOC (Figure 1) is transported to the laboratory as quickly as possible to minimize deterioration, ideally within minutes of collection. "Time zero" samples are processed concomitant with 


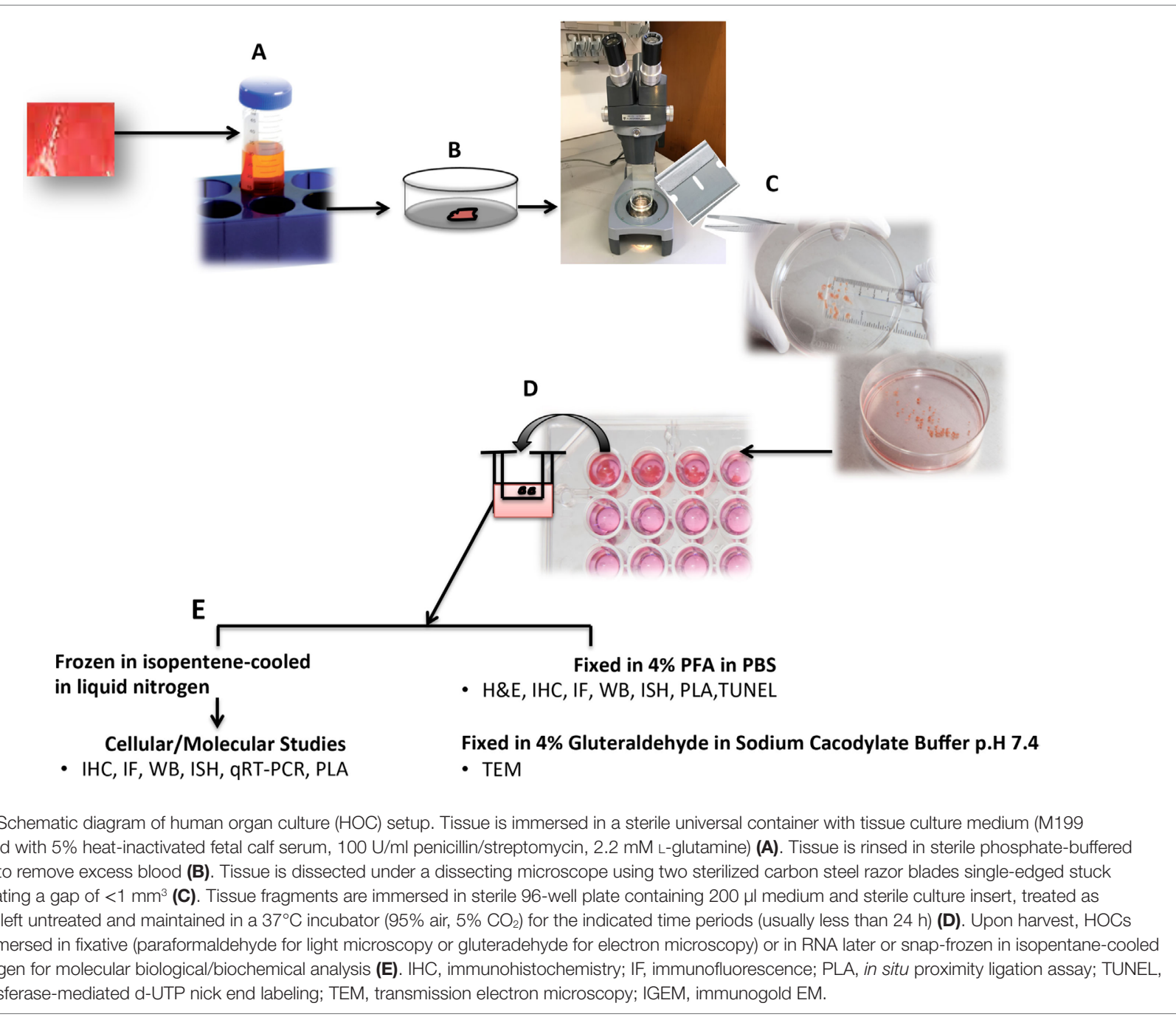

the onset of organ culture to establish morphological features prior to culture and treatments. Excess blood can be removed by immersing tissue in sterile phosphate-buffered saline prior to transfer into a sterile petri-dish for dissection into $<1 \mathrm{~mm}^{3}$ fragments using two sterilized carbon steel single-edged razor blades (T585; Agar Scientific, UK) stuck together under a dissecting microscope (to aid in sample selection and orientation). However, other groups have documented use of various tools for dissecting tissue for OCs such as a Leica VT1200 S vibrating blade microtome with Vibrocheck (1), a biopsy punch $(2,3)$, motor-driven coring tool (4), and a Krumdieck tissue slicer (1, 5). For each tissue, multiple samples can be collected from different regions. For example, in the kidney samples can be taken from the medulla through to the cortex. The dissected fragments are immediately immersed in $200 \mu \mathrm{l}$ of tissue culture medium (e.g., M199 containing 5\% heat-inactivated fetal calf serum, $100 \mathrm{U} / \mathrm{ml}$ penicillin/streptomycin, $2.2 \mathrm{mM} \mathrm{L}$-glutamine) in a sterile 96 -well plate containing culture inserts, treated as indicated, or left untreated and maintained in a $37^{\circ} \mathrm{C}$ incubator (95\% air, 5\% $\mathrm{CO}_{2}$ ) for the desired time periods (usually less than $24 \mathrm{~h}$ ). Culture conditions may need to be altered depending upon the tissue source, but we have successfully used this formulation for kidney, heart, and skin HOCs. Replicate samples for each treatment and time point are used to assess reproducibility. In our experience, we observe a rapid deterioration of morphology in culture of kidney samples incubated for longer than $18 \mathrm{~h}$. During incubation, organ cultures remain metabolically and physiologically active and respond to external stimuli. Upon harvest, HOCs can be immersed in fixative (e.g., paraformaldehyde for light microscopy or gluteradehyde for electron microscopy), or in RNA later, or snap-frozen in isopentane-cooled in liquid nitrogen for molecular biological/biochemical analysis. Organ cultures of human kidney, heart, skin, and tumors can all be conducted using similar technique (6-10).

\section{METHODS THAT CAN BE APPLIED ON HOCs}

Advances in molecular and biochemical techniques have increased the power of HOCs (Table 1). The ability to perform replicate cultures that can be sampled throughout a treatment 
TABLE 1 | Methodologies that can be used to analyze human organ cultures and key findings.

\begin{tabular}{|c|c|c|c|}
\hline Type of explants & Methodology & Key findings & Reference \\
\hline Human skin & $\Vdash \mathrm{HC}$ & E-selectin is a marker for activation of endothelial cells (ECs) & (23) \\
\hline $\begin{array}{l}\text { Normal human skin } \\
\text { and skin with psoriasis }\end{array}$ & $\begin{array}{l}\text { Autoradiography, } \mathrm{IHC} \text {, } \\
\text { biochemical methods }\end{array}$ & $\begin{array}{l}\text { [125] EGF binding was increased in psoriatic epidermis compared } \\
\text { to normal skin, and increased EGF receptor phosphorylation }\end{array}$ & $(26)$ \\
\hline Newborn foreskins & TEM, IGEM, IHC & $\begin{array}{l}\text { Microvascular endothelium of skin can undergo activation in response } \\
\text { to exogenous/endogenous cytokines, with most pronounced changes } \\
\text { seen at sites involved in leukocyte trafficking }\end{array}$ & (22) \\
\hline Neonatal skin & $\mathrm{HC}, \mathrm{WB}$ & $\begin{array}{l}\text { Cytokines known to be present in psoriatic skin induce EGF/TGF- } \alpha \text { receptor } \\
\text { and TGF- } \alpha \text { expression in neonatal skin }\end{array}$ & $(27)$ \\
\hline New born human foreskin & $\mathrm{HC}$ & Demonstrated mediators involved in the induction and regulation of ICAM-1 & $(15)$ \\
\hline Human skin & $\mathrm{IHC}, \mathrm{IEM}$ & Cytokine responses of microvasculature is altered in psoriasis & (31) \\
\hline $\begin{array}{l}\text { Human umbilical artery } \\
\text { and vein }\end{array}$ & $\begin{array}{l}\text { Gene delivery using adenovirus } \\
\text { vectors in cultures }\end{array}$ & $\begin{array}{l}\text { Demonstrated that adenovirus vectors are not of value for gene delivery to } \\
\text { uninjured vascular endothelium in situ, and are unlikely to be suitable for } \\
\text { genetic manipulation for vascular endothelium in organs for transplantation }\end{array}$ & $(41)$ \\
\hline $\begin{array}{l}\text { Human tonsillar and } \\
\text { appendix }\end{array}$ & WB & $\begin{array}{l}\text { Demonstrated protein expression of mediators involved in upregulation } \\
\text { of endothelial VAP-1 }\end{array}$ & $(13)$ \\
\hline $\begin{array}{l}\text { Human saphenous vein } \\
\text { (de-endothelialized) }\end{array}$ & $\begin{array}{l}\text { Histochemical stains (van Giessen, } \\
\text { Miller's elastic), H\&E, IHC }\end{array}$ & $\begin{array}{l}\text { ANG II increased DNA synthesis to a greater extent than in isolated cell cultures } \\
\text { of saphenous vein smooth muscle cells, mediated in part by angiotensin receptor } 1\end{array}$ & $(49)$ \\
\hline Human skin & $\begin{array}{l}\text { WB, RT-qPCR, geletainolytic } \\
\text { zymogram }\end{array}$ & $\begin{array}{l}\text { Demonstrated multiple cytokines can regulate expression of MMP-9 transcript } \\
\text { and protein and in human skin }\end{array}$ & $(18)$ \\
\hline Human saphenous vein & $\begin{array}{l}\text { MTT, Hoechst 333258, TUNEL, } \\
\text { H\&E, Verhoeff's Van Gieson }\end{array}$ & $\begin{array}{l}\text { Early molecular events occurring in the arterialization of human vein grafts are } \\
\text { controlled by hemodynamic conditions }\end{array}$ & $(67)$ \\
\hline $\begin{array}{l}\text { Normal cervical tissue } \\
\text { and CIN II/III lesions }\end{array}$ & $\mathrm{IHC}$ & $\begin{array}{l}\text { rhTRAIL and MG132, a proteosomal inhibitor, synergize to induce apoptosis, } \\
\text { especially in CIN II/III lesions }\end{array}$ & (2) \\
\hline Human umbilical tissue & RT-qPCR, IHC, FACS, WB & $\begin{array}{l}\text { Arterial and venous ECs in cultured human umbilical tissue activate different } \\
\text { transcription factors and upregulate different adhesion molecules in response to TNF }\end{array}$ & $(24)$ \\
\hline $\begin{array}{l}\text { First trimester human } \\
\text { placental villous and } \\
\text { extravillous tissue }\end{array}$ & siRNA, WB & $\begin{array}{l}\text { Silencing of GCM1 upregulated by forskolin treatment resulted in cell } \\
\text { proliferation and promoted de novo syncitiotrophoblast formation in } \\
\text { syncytially denuded floating villous explants }\end{array}$ & $(46)$ \\
\hline $\begin{array}{l}\text { Human skin adhered } \\
\text { to acellular dermis }\end{array}$ & $\begin{array}{l}\text { RT-qPCR, IHC, histometric } \\
\text { analyses, WB }\end{array}$ & HRG-activated HER3 contributes to the outgrowth process of epidermis & (30) \\
\hline $\begin{array}{l}\text { Healthy skin and skin } \\
\text { from patients with ESRD }\end{array}$ & IHC, WB, ELISA & $\begin{array}{l}\text { Production of MMP1, TIMP-1 but not type I procollagen is increased in } \\
\text { skin of ESRD-treated with omniscan (gadodiamide). Indicated omniscan } \\
\text { alters enzyme/inhibitory system responsible for collagen turnover in the skin } \\
\text { and directly stimulates hyaluronan production }\end{array}$ & (36) \\
\hline $\begin{array}{l}\text { Normal human kidney, } \\
\text { and renal transplants } \\
\text { undergoing ACR and ATN }\end{array}$ & IHC, ISH, TUNEL & $\begin{array}{l}\text { TNFRs are differentially regulated and activate different signaling pathways in } \\
\text { normal, inflamed and ischemic human kidney }\end{array}$ & (9) \\
\hline Human tonsil & Histology, IHC, and histochemistry & $\begin{array}{l}\text { Reported preservation of structure and function in normal and neoplastic } \\
\text { colon tissue }\end{array}$ & (39) \\
\hline Human skin & $\mathrm{HC}, \mathrm{FACS}$ & $\begin{array}{l}\text { Lentiviral tropism in skin tissue is distinct from tropism to keratinocytes in } \\
\text { culture, and dependent on three-dimensional architecture of the tissue }\end{array}$ & $(42)$ \\
\hline Human neonatal foreskin & $\begin{array}{l}\text { DNA extraction/Dot blot by } \\
\text { image density quantification, } \mathrm{IHC}\end{array}$ & Detected UV-induced DNA damage and repair in skin & (43) \\
\hline $\begin{array}{l}\text { Normal human kidney } \\
\text { and RCC explants }\end{array}$ & $\mathrm{IHC}$ & $\begin{array}{l}\text { Resident cancer stem cells are increased in RCC. Selective ligation of } \\
\text { TNF receptor } 2 \text { can induce stem cell proliferation, increasing susceptibility } \\
\text { to cell cycle-dependent cytotoxicity }\end{array}$ & $(10)$ \\
\hline \multirow[t]{2}{*}{$\begin{array}{l}\text { Human saphenous vein } \\
\text { and coronary artery }\end{array}$} & $\begin{array}{l}\text { H\&E, histochemical stains } \\
\text { (Alcian blue, Miller's elastin, } \\
\text { and Van Gieson) }\end{array}$ & Quantified cell numbers and neointimal area in vascular cultures & (20) \\
\hline & $\begin{array}{l}\text { Chemokine multiplex immunoassay, } \\
\amalg \mathrm{HC} \text {, WB, histology, saturation and } \\
\text { competition analysis, RT-qPCR }\end{array}$ & $\begin{array}{l}\text { CCR- } 5 \text { mRNA and protein in venous smooth muscle consistent with } \\
\text { receptor binding, and that CCL } 4 \text { and CCL5 are vasoconstrictors in the } \\
\text { human saphenous vein }\end{array}$ & \\
\hline Human prostate cancer & Adenoviral gene delivery, IHC & $\begin{array}{l}\text { STAT5a/b induces epithelial-to-mesenchymal transition in human } \\
\text { prostate cancer }\end{array}$ & (48) \\
\hline
\end{tabular}


TABLE 1 | Continued

\begin{tabular}{|c|c|c|c|}
\hline Type of explants & Methodology & Key findings & Reference \\
\hline $\begin{array}{l}\text { Normal human kidney and } \\
\text { renal clear cell carcinoma } \\
\text { (RCC) }\end{array}$ & IHC, TUNEL, IGEM, In situ PLA & $\begin{array}{l}\text { Expression of TNFRs and signaling pathways activated are different } \\
\text { in RCC compared to normal kidney }\end{array}$ & $(8,10)$ \\
\hline $\begin{array}{l}\text { Human colon and } \\
\text { pulmonary biopsies }\end{array}$ & siRNA, WB & $\begin{array}{l}\text { Silencing of Cyclin D1 expression by siRNA delivered by invivofectamine } \\
\text { or nanoliposomes in colon but not lung organ cultures }\end{array}$ & $(47)$ \\
\hline \multirow[t]{3}{*}{$\begin{array}{l}\text { Precision-cut human } \\
\text { kidney slices }\end{array}$} & $\begin{array}{l}\text { CytoTox-ONE homogeneous } \\
\text { membrane integrity assay }\end{array}$ & Measurement of ATP content and LDH leakage indicated viability of cultures & (3) \\
\hline & HPLC & $\begin{array}{l}\text { Measurement of uridine } 5 \text { diphospho-glucuronosyl transferase } \\
\text { indicated cell functionality in cultures }\end{array}$ & \\
\hline & WB, RT-qPCR & $\begin{array}{l}\text { Determined TGF } \beta 1 \text {-induced activation and upregulation of fibrotic } \\
\text { markers at the RNA and protein level }\end{array}$ & \\
\hline
\end{tabular}

ESRD, end-stage renal disease; GCM1, glial cell missing-1; H\&E, hematoxylin and eosin; IHC, immunohistochemistry; WB, western blot; RT-qPCR, real-time quantitative polymerase chain reaction; FACS, fluorescence activated cell sorting; siRNA, small interference ribonucleic acid; ELISA, enzyme-linked immunosorbent assay; HPLC, high performance liquid chromatography; TGF- $\alpha$, transforming growth factor alpha; TGF, transforming growth factor; ATP, adenosine triphosphate; LDH, acetate dehydrogenase; VAP-1, vascular adhesion protein-1; rhTRAlL, recombinant human tumor necrosis factor (TNF)-apoptotic inducting ligand; TNFRs, TNF receptors; GCM1, glial cells missing homolog 1; HRG, high heregulin; EGF, epidermal growth factor; RCC, renal clear cell carcinoma; ACR, acute cellular rejection; ATN, acute tubular necrosis; NK, normal kidney; ICAM-1, intracellular adhesion molecule; TUNEL, terminal transferase-mediated d-UTP nick end labeling; LPS, lipopolysaccharide; ANG II, angiotensin II; CIN, cervical intraepithelial neoplasia; PLA, proximity ligation assay; IGEM, immunogold electron microscopy; TEM, transmission electron microscopy; STAT, signal transducer and activator of transcription; CCR-5, C-C chemokine receptor type 5; CCL, chemokine (C-C motif) ligand; VSMC, vascular smooth muscle cell; MMP, matrix metalloproteinase; TIMP, tissue inhibitors of metalloproteinase; HER, human epidermal growth factor.
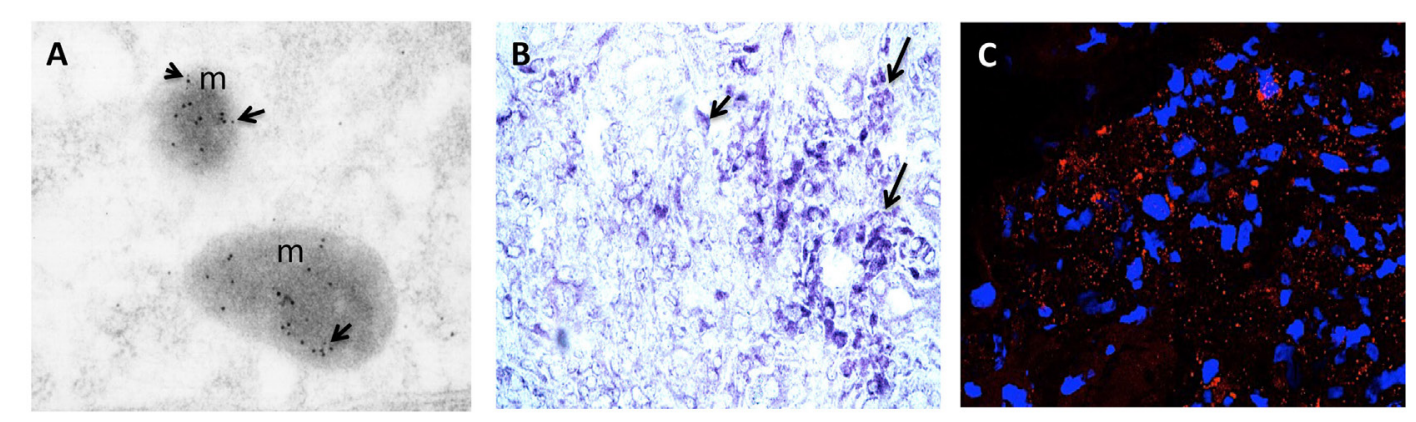

FIGURE 2 | (A) RCC organ cultures treated with recombinant human TNF for $3 \mathrm{~h}$ and subjected to immunogold electron microscopy. Colloidal gold particles representing localization of phospho-MLKL (Ser358) $(5 \mathrm{~nm})$ and phospho-dyamin-related protein-1 (Drp1) (Ser616) (10 nm) and are detected in mitochondria (m). Mag: 105kx. (B) Representative light micrograph of RCC organ cultures treated with recombinant human TNF for $3 \mathrm{~h}$ were subjected to in situ hybridization using anti-sense probe to RIPK3 conjugated with Digoxigenin (DIG). Intense blue staining using anti-DIG-alkaline phosphatase and BCIP/NBT substrate (blue color) is seen in sites of gene expression within the cytoplasm of tumor cells. Original mag: 63x. (C) Representative confocal image of RCC organ cultures treated with recombinant human TNF for $3 \mathrm{~h}$ and subjected to in situ proximity assay to determine interaction between RIPK3 and phosphorylated-MLKL (Ser358). Numerous strong red fluorescent spots are evident within the cytoplasm of malignant TECs (mTECs) indicating close proximity of RIP3/pMLKL ( $<40 \mathrm{~nm})$. Original mag: 63x. TNF, tumor necrosis factor.

period and the resolution offered by advances in labeling and imaging technologies allows detailed analysis of responses of both spatial and temporal to treatment within a tissue at a molecular level. Confocal microscopy can resolve molecules in the $200 \mathrm{~nm}$ ranges, and immunogold electron microscopy provides opportunities to resolve the cellular localization and phosphorylation status of proteins at a resolution of $<10 \mathrm{~nm}$ (Figure 2A). Localization of gene expression can be studied using in situ hybridization (Figure 2B). New technologies can extend the potential of traditional immunolocalization assays to study molecular interactions. The in situ proximity ligation assay can be used to detect single molecules at a subcellular level and detect protein interactions in response to external stimuli (Figure 2C). The application of this technique to HOC provides the capability to study dynamic molecular interactions in situ with high spatial resolution.

\section{HOCs PRESERVE CELLULAR RESPONSES THAT MAY BE LOST IN CELL CULTURES}

Human organ cultures can be used to study physiological responses to mediators that are lost in cell cultures. For example, in organ cultures of normal human kidney, TGF- $\beta 1$ promotes fibrogenesis in parallel with increased expression of multiple fibrotic markers including heat shock protein 4, fibronectin 1 , type $1 \mathrm{~A}$ collagen (COL1A 1$)$, and $\alpha$-smooth muscle actin $(\alpha$-SMA), but not vimentin, E-cadherin, and CD31. TGF- $\beta 1$ pathway also increases plasminogen activator inhibitor 1 , a downstream signaling molecule (3). These various responses to TGF- $\beta 1$ differ from those seen in primary cultures or cell lines derived from different renal cell types $(11,12)$. In human tonsil organ cultures, pro-inflammatory cytokines, such as TNF, 
IL-1, IL-4, IFN- $\gamma$, and lipopolysaccharide (LPS) each induce marked upregulation of vascular adhesion protein (VAP)-1, a molecule important for leukocyte recruitment across high endothelial venules of secondary lymphoid organs $(13,14)$. Cultured endothelial cells (ECs), including ECs cultured from human tonsil, fail to express VAP-1 when exposed to these same agents. In human skin organ cultures, IFN- $\gamma$ induces ICAM-1 expression primarily on ECs and epidermal keratinocytes (KCs) whereas IL-6, GM-CSF and macrophage-CSF induce ICAM-1 expression on both ECs and dermal dendritic cells (DCs) but not KCs. IL- $1 \alpha$ or IL- $\beta$ induce ICAM- 1 expression on DCs while TNF affects primarily ECs and IL-3 does not affect any cell type (15). These varied responses to cytokines again differ from those of human dermal ECs and KCs in cell culture (16). In the same HOC system, the expression of the major histocompatibility antigens (MHC) class II (HLA-DR/DQ) is induced by IFN- $\gamma$ in microvascular ECs and epidermal DCs [Langerhans cells (LC)] but not on KCs whereas IFN- $\gamma$ does induce MHC class II molecules on cultured human KCs (17). Also in skin organ cultures, pro-MMP-9 expression is induced by TGF $\beta$, which is increased by TNF (18). TNF (but not TGF $\beta$ ) promotes proteolytic activation of pro-MMP-9 by conversion of the $92-\mathrm{kDa}$ pro-MMP-9 to the $82-\mathrm{kDa}$ active enzyme. This TNF-mediated proteolytic activation of pro-MMP-9 is undetected in isolated cultures of dermal fibroblast or epidermal KCs (19). In HOCs of saphenous vein both contractile and proliferative vascular smooth muscle cells (VSMCs) express CCR-5, a chemokine receptor implicated on atherosclerosis, in response to ligands CCL4 and CCL5 (20). In contrast, cultured VSMCs from human saphenous vein do not express CCR-5 when similarly stimulated (21).

\section{HOCs CAN REVEAL POSITIONAL EFFECTS UPON CELLULAR RESPONSES}

Endothelial cells play a key role in many different disease processes and while they are often considered as a single cell type, their phenotype, functions, and responses to stimuli in vivo are very sensitive to anatomic position. For example, the superficial vascular plexus (SVP) of human skin allows ready distinction of arterioles, capillaries, and venules with capillary arcades confined to the dermal papillae that nurture the epidermis and with paired arterioles and venules running parallel to the epidermal layer but below the epidermal rete. In response to TNF or LPS, only ECs lining postcapillary venules (PCV) of the SVP will express E-selectin (22), i.e., the same vessel segments typically associated with inflammatory infiltrates in vivo in elicited delayed-type hypersensitivity reactions (23). In the same HOCs, ECs lining arterioles and capillaries are responsive to these same mediators by increasing their expression of ICAM-1. In other words, the anatomic position of the ECs determines how, but not whether the ECs respond to specific inflammatory stimuli. In contrast, all cultured human dermal ECs will upregulate E-selectin and ICAM-1. Similarly, in HOCs of umbilical cords, where the paired arteries and single vein are also readily distinguished, the ECs lining umbilical veins respond to TNF by expressing E-selectin, whereas ECs lining umbilical arteries will not. In the same HOCs, arterial ECs respond to TNF by expressing higher levels of ICAM-1 than do umbilical vein ECs. Remarkably, these differences begin to narrow in as little as a few hours and are completely erased by 3 days in cell culture, at which time both arterial and venous ECs assume a common phenotype that differs from both types of ECs in situ and show intermediate degrees of both ICAM-1 and E-selectin induction. The change in the behavior of arterial ECs upon harvest and cell culture has been attributed to loss of shear stress-induced modifiers of the TNF response such as Kruppel-like factor 2, but the changes in venous EC, which also show loss of shear stress-induced factors, albeit from lower starting levels, are in the opposite direction of those observed in arterial ECs (24). The rapidity of the alterations in cytokine responses upon isolation supports the interpretation that the differences in TNF responses are determined by the microenvironmental context in which these cells are located, for example on distinct types of basement membrane, rather than by stable epigenetic changes. Thus, even though cell culture experiments allow the discovery and evaluation of cytokine actions on ECs, cultured ECs lose the ability to identify responses that vary with the anatomic origin of the cell, a feature amenable to study in HOCs. This loss of positional responses in human umbilical veins ECs occurs in both $2 \mathrm{D}$ and $3 \mathrm{D}$ cultures. Remarkably, when Bcl-2 transduced human umbilical vein ECs, which are indistinguishable from control ECs in 2D culture, are placed into 3D cultures and then implanted into immunodeficient mice, they form vessels that become perfused and acquire arteriolar, venous, and capillary morphologies and gain characteristic segmental responses to TNF. To date, organoid cultures that form vessels do not allow distinctions among vascular segment types.

\section{HOCs CAN BE USED TO STUDY STEM CELLS}

Human organ cultures can be used to study stem cells within their niche. For example, in human cardiac tissue affected by ischemic heart disease, resident stem cells, identified as small round cells that express CD133 but not CD45, express TNF receptor 2 (TNFR2) and respond to TNF, in a manner dependent upon TNFR2 signaling, by entering cell cycle and expressing characteristic markers of mature cardiomyocytes (7). This potentially beneficial response of resident cardiac stem cells to TNF may have contributed to the adverse effects of anti-TNF therapies in human heart failure. HOCs can also allow comparisons of normal and tumor stem cells. Renal organ cultures also contain CD133 ${ }^{+}$ resident stem cells, which are more abundant in renal clear cell carcinoma (RCC) than in normal kidney. In organ cultures of RCC and corresponding non-tumor kidney, TNFR2 engagement on $\mathrm{CD}_{133^{+}}$resident stem cells results in increased TNFR2 expression and promotes cell cycle entry. Importantly, while TNFR2 effects are not directly harmful to these stem cells, TNFR2driven cell cycle entry increases their sensitivity to cell cycledependent cytotoxic agents (10). These findings have indicated that priming tumor stem cells with a TNFR2 agonist may enhance the efficiency of chemotherapy for RCC. 


\section{HOCs CAN REVEAL ALTERED RESPONSES AND SIGNALING PATHWAYS IN DISEASE}

\section{Inflammatory Diseases}

Human organ cultures of skin from patients have provided insights into inflammatory disease pathogenesis. Psoriasis vulgaris, which displays hyperproliferation of the epidermal $\mathrm{KCs}$, is characterized by overexpression and altered distribution of the EGF/TGF- $\alpha$ receptor, and of TGF- $\alpha$ itself. In normal stratified epithelium, the expression of EGF/TGF- $\alpha$ receptor is restricted to the basal and intermediate suprabasal KCs (25). However, in active psoriatic lesions, expression of EGF/TGF- $\alpha$ receptor is seen in the basal and subcorneal layers of stratified epithelium (26). TNF and IFN- $\gamma$ induce EGF/TGF- $\alpha$ receptor expression in basal and suprabasal cells in non-stimulated explants in KCs in all layers of the epidermis (27). In contrast primary cultures of KCs cannot reproduce these positionrelated differences $(28,29)$. Moreover, treatment of skin HOCs with EGFR family members increases keratinocyte proliferation and neoepidermal thickness (30), mimicking psoriasis-like changes. ECs of the SVP in skin HOCs generated from psoriatic lesions, sites uninvolved by lesions and perilesional skin from the same patient provide an additional example of diseaserelated altered responses. The ECs in cultures from uninvolved sites and perilesional sites do not show expression of E-selectin and VCAM-1, whereas in lesional skin, both molecules are expressed on ECs of PCV and, significantly, on the ECs lining the remodeled (venularized) capillaries in the dermal papillae of the SVP. In skin HOCs from uninvolved sites, similar to skin HOCs from healthy donors, TNF induces E-selectin on the ECs lining PCVs whereas VCAM-1 is not inducible on these same cells, even when TNF is combined with IL-4. However, in perilesional skin biopsies from psoriatic patients, which is devoid of leukocytes, VCAM-1 can be induced on SVP venular ECs by the combination of TNF and IL-4, suggesting a change in the responsiveness of these ECs related to a disease process that precedes overt plaque spreading (31).

Human organ cultures of normal and pathologic colon have demonstrated that different bacterial species adhere in a peculiar manner to the proximal and distal colonic compartments of the mucosal surface (32). A consistent adhesion of Streptococcus thermophillus and Bifidobacterium infantis but not Lactobacillus acidophilus, with $B$. infantis adhering to the proximal compared to the distal segments. In contrast to cell cultures of human intestinal epithelial cell lines, which show differential adhesion profiles of bacterial strains (33), with $L$. acidophilus as the most adherent strain in intestinal mucosa (34). Findings from cell cultures for bacterial adherence capacity to epithelial cells are difficult to extend to the situation in the human gastrointestinal tract and it is unknown if intestinal organoids will be more useful in this regard.

\section{Systemic Diseases}

Human organ cultures of skin have been used to study how systemic processes may influence cutaneous responses. Magnetic resonance imaging gadolinium-based contrast agents (GBCAs) appear to be a trigger of nephrogenic systemic fibrosis in a small subset of patients with end-stage renal disease (ESRD) (35). DaSilva et al. (36) compared responses to GBCAs in human skin organ cultures and in isolated dermal fibroblast and KC cultures, using skin from individuals with ESRD and from normal individuals. Skin organ cultures treated with GBCA (Omniscan) show increased MMP1 production, TIMP-1 and hyaluronan production but not collagen type-1. Responses were seen in patients with ESRD and controls, but basal levels were higher in patients with ESRD. These potentially pathogenic responses were detected in $\mathrm{KCs}$ in monolayer culture, and although similar responses were observed in fibroblasts, there was no difference in responses in $2 \mathrm{D}$ cultured fibroblasts isolated from the skin of normal patients as compared to patients with ESRD.

\section{Organ Transplantation}

Cytokine effects in human kidney are cell type specific and also depend on anatomical location. In normal kidney, ECs of glomerular and peritubular capillaries (PTCs) express higher levels of TNF receptor 1 (TNFR1) associated with inactive apoptosis signal-regulating kinase-1 (ASK1 $\mathrm{p}^{\text {Ser967) }}$ ) and an absence of activated ASK1 (ASK1 ${ }^{\text {Thr845 }}$ ). Other renal cell types lack both TNFR1 and ASK1. TNFR2 is only minimally expressed in any cell type in normal kidney. This expression pattern of TNFRs differentiates renal cells in situ from cultured renal cells where both receptors are typically expressed in the same cell. It also differs from the patterns seen in rejecting renal allografts or ischemia reperfusion injury where resident renal cells lose TNFR1 expression and ECs of PTCs and tubular epithelial cells (TECs) express TNFR2 (9). Effects of TNF signaling on different renal cell populations can be analyzed in organ cultures. Treatment of normal kidney organ cultures with a TNFR1selective mutein results in activation of ASK1 and induction of cell death in ECs of glomerular and PTC, while a TNFR2selective mutein upregulates TNFR2, results in phosphorylation of endothelial-epithelial tyrosine kinase (Etk) and initiates cell cycle entry in ECs of PTC and in TECs. TNF does not affect the expression of either receptor in cultured renal cells. In kidneys injured by allograft rejection, despite showing reduced or even absent expression of TNFR1, activated ASK1 $\mathrm{p}^{\text {Thr845 }}$ is seen in both ECs and TECs, and this has been linked to expression of an alternative receptor, DR3, that is absent from cultured renal cells (9)

\section{Cancer}

In RCC organ cultures, a TNFR1-selective mutein promotes cell death in malignant TECs (mTECs) selectively expressing ASK1, with the majority of the cells dying via necroptosis involve the receptor-interacting protein (RIP1)/RIP3/phosphorylated mixed lineage kinase domain like (MLKL)/dyamin-related protein-1 (Drp1). As an example of how modern morphological approaches can be applied in HOCs, physical interactions between signaling intermediates have been demonstrated using in situ proximity ligation assay. In the same HOC system a TNFR2-selective mutein promotes cell cycle via reciprocal phosphorylation of Etk and vascular growth factor receptor 2 
(VEGFR2) in mTECs, whereas VEGF activates VEGFR2, but not Etk, suggesting Etk-VEGFR2 interactions and cell cycle activation in mTECs are specific to TNFR2 signaling. TNFR2 expression increases with increasing cancer grade providing a model to study the effects of regulated expression of the receptor in a pathophysiological setting. These data have important therapeutic implications, suggesting that inhibitors of VEGFR may be more effective than neutralization of VEGF because TNF-TNFR2 signaling may provide an alternative and possibly more effective VEGF-independent means to activate this mitogenic receptor (8). Once again, this behavior revealed in organ culture cannot be replicated in isolated cell cultures of human TEC lines (DPK-KTEC-H and HK2). In the context of brain tumors, tumor cells' susceptibility to TNF-related apoptosisinducing ligand (TRAIL) and lack of activity in healthy cells led to speculation that TRAIL could be used in cancer therapy (37). However, in organ cultures of adult human brain slices, trimerized TRAIL increased death in a large number of cells in the cortex and white matter as compared to untreated cultures with damaged cells identified as neurons, oligodendrocytes, astrocytes, and microglial cells (38). Another study examined the role of calcium $\left(\mathrm{Ca}^{2+}\right)$ /calcium-sensing receptor (CaSR) in regulation of growth and differentiation in normal and malignant colon HOCs (39). Lower third of the crypt in normal cultures showed proliferation while extracellular CaSR expression was present in the surface epithelium and upper third. E-cadherin and $\beta$-catenin were expressed at the cell surface between adjacent cells. In malignant tissue, in contrast to normal tissue, proliferation was detected throughout the epithelium with diffuse or absence of CaSR. Expression of $\beta$-catenin was detected throughout the cytoplasm and nucleus. Expression of E-cadherin was seen at the cell surface (as in the normal tissue) with diffuse expression throughout the cytoplasm in some areas. In contrast to colon carcinoma cells where extracellular $\mathrm{Ca}^{2+}$ did not induce E-cadherin or result in a shift in $\beta$-catenin from the cytoplasm to the cell membrane, $\mathrm{Ca}^{2+}$ treatment resulted in growth reduction in mock-transfected cells and in a $\mathrm{Ca}^{2+}$-responsive variant line derived from the same parental colon carcinoma cells. This was accompanied by increased production of E-cadherin and a shift in $\beta$-catenin distribution from the cytoplasm to the cell membrane (40).

\section{HOCs CAN BE USED TO STUDY THERAPEUTICS}

Human organ cultures of blood vessels have been used to determine gene delivery efficiency of a replication-defective adenovirus 5 vector carrying the [beta]-galactosidase reporter gene to vascular ECs (41). In contrast to cultured human primary vascular ECs, which were efficiently infected ( $>90 \%)$ at adenovirus concentrations of $>10^{10} \mathrm{pfu} / \mathrm{ml}$, non-dividing vascular endothelium in situ was very poorly transduced, casting doubt on the utility of this class of vector in vivo. Similarly, skin HOCs have been used to characterize the factors that determine lentiviral vector tropism and findings compared to monolayer cultures of KCs (42). While early monolayer cultures of progenitor KCs expressing keratin
$15^{+} / 63^{+}$are lentiviral vector-permissive, they are resistant to transduction in their native niche in the skin. Alternatively, transiently amplified keratin $14^{+} \mathrm{KCs}$ are permissive to lentiviral transduction, in cell culture and in the skin, after separation of epidermis from dermis layer. Keratin $14^{+} \mathrm{KCs}$ in the human skin hair follicles are resistant to lentiviral transduction even after partial digestion of the extracellular matrix (ECM) collagen. Thus lentiviral vector tropism to KCs in organ culture is distinct from tropism to KCs in cell culture.

In HOCs of skin, topical imiquimod, a pharmacological agent that facilitate the development of skin cancer through accumulation of genetic lesions failed to enhance DNA repair after UV-exposure (43). In contrast to imiquimod-treated epidermal bone marrow-derived cells (BMDCs) (43), attributing these differences to the KCs in the epidermal layer lacking TLR7/8 while BMDCs such as LCs express TLR7/8 (44). A differential response to imiquimod has also been observed in stimulated KCs monolayers (HaCaT cells, immortalized human KCs and primary KCs), which failed to show DNA repair in contrast to stimulated KG-1, a monocytic cell line (43). These data suggested that LCs activated by imiquimod might potentially influence neighboring KCs and thus provide an indirect protection against UV damage. HOCs of normal squamous cervical tissue and CIN II/III lesions have been used to evaluate the effect of a potential anticancer drug rhTRAIL (recombinant human TRAIL) alone or in combination with a proteasome inhibitor MG132 (2). MG132 induced increased sensitivity in CIN II/III cultures as compared to normal cultures, which was enhanced by treatment with rhTRAIL. In contrast, immortalized and transformed cells lines, which serve as a model for cervical carcinogenesis, show variable sensitivity to proteosomal inhibition to rhTRAIL (45). Among the human cervical cancer cell lines HeLa were moderately, CaSki was highly and SiHa was insensitive to rhTRAIL-induced apoptosis. However, MG132 resulted in a marked rhTRAIL-induced cell death in HeLa and $\mathrm{SiHa}$ in a time- and caspase-dependent manner. HOCs can also be treated with various pharmacological inhibitors, short interfering RNAs (siRNA), or anti-sense oligonucleotides to gain insights into molecular function of cells in situ (46-48). In human colon and lung organ cultures, stimulus LPS-activated endothelium (EC-LPS), induced a marked expression of Cyclin D1. Treatment of cultures with siRNA for Cyclin D1, in presence or absence of EC-LPS, resulted in approximately $46 \%$ reduction of Cyclin D1 compared to the basal condition, and by approximately $65 \%$ compared to colon samples treated with EC-LPS after $24 \mathrm{~h}$ (47). In organ cultures of prostate cancer, in which Stat5a/b-mediates epithelial-to-mesenchymal transition (EMT) (epithelial-mesenchyme transition), disruption of Jak2/ Stat $5 \mathrm{a} / \mathrm{b}$ signaling by specific inhibitors resulted in a significant decrease in active nuclear Stat $5 \mathrm{a} / \mathrm{b}$ but not Stat 3 , increase levels in E-cadherin and simultaneously a decrease in levels of Twist1 indicating that active $S$ tat $5 \mathrm{a} / \mathrm{b}$ signaling promotes expression of EMT markers (48). In studies of first trimester human placental explants denuded of villous cytotrophoblasts, siRNA and antisense oligonucleotides silencing of GCM1 (glial cell missing-1 transcription factor), which mediates syncytialization and proliferation, resulted in a strong inhibition of syncytiotrophoblast 
reformation, and increased proliferation of cytotrophoblast (46). In organ cultures of human de-endothelialized saphenous veins, an effector peptide of the renin-angiotensin system Angiotensin II (Ang II), induced a strong increase in DNA synthesis over 7 days, associated with increased proliferation and hyperplasia in media of vein. Treatment of cultures with Tyrphostin-23; a selective inhibitor of tyrosine kinases significantly abolished the effects of Ang II while PD123319, a selective $\mathrm{AT}_{2}$ receptor antagonist had no significant effect on the Ang II response (49). In contrast Ang II failed to stimulate DNA synthesis in cultured SMCs from human saphenous vein or from human coronary arteries $(50,51)$.

\section{COMPARISON OF HOCs TO EMERGING CELL CULTURE METHODS}

\section{D Cultures}

A wide range of $3 \mathrm{D}$ in vitro models is emerging to better mimic the human physiology and, at the same time, to reduce animal experiments (52). 3D cultures use different types of porous scaffolds, derived from naturally and engineered substrates (53). Gene expression profiles of cancer cells often differ in cells grown in $3 \mathrm{D}$ as compared to $2 \mathrm{D}$ cultures. In particular genes involved in angiogenesis, proliferation, invasion, migration, and chemosensitivity (54). 3D cultures have been used to determine the effects of cytokines (55) and cells seeded into a 3D cardiac ECM scaffold have shown increased calcium signaling and kinetics promoting stem cell maturation (56). However, in contrast to HOCs, ECM scaffolds used in $3 \mathrm{D}$ cultures fail to emulate the natural biochemical and physical properties of the ECM recognized as independent factors that influence cell activity (57). Furthermore, basement membrane-derived scaffolds may contain undesired components like viruses and growth factors. Indeed, other matrices permit cell attachment but not easy detachment of cell making assay development difficult. Even with the generation of 3D biological scaffolds via organ de-cellularization (58), current systems fail to offer complex in vivo tissue vasculature for supply of nutrients and oxygenation as well as removal of waste material necessary for promoting attachment, differentiation, and proliferation of cells. Moreover, clonal variation across various strains of cell lines and 3D culture techniques used in different laboratories may also influence data. Unlike HOC, cell lines used in $3 \mathrm{D}$ cultures lose many of their native in vivo characteristics once removed from the primary tissue. Moreover, most research that uses in vitro models ignores the origins of cell lines and histological characteristics because of the unavailability of these data. For example, SKOV3, an epithelial ovarian cancer cell line widely used in $3 \mathrm{D}$ in vitro model for studying ovarian cancer bears striking histological resemblance to a clear cell ovarian cancer, which is the least common histological subtype of invasive disease (59).

\section{D Bioprinting}

This system incorporates biology and tissue engineering to develop biological substrates that restore, improve, and maintain tissue function. The three most common 3D-bioprinting mechanisms include inkjet (a non-contact printing technology that reproduces digital patterns onto a substrate using tiny ink drops), laser (uses laser energy to vaporize the solution of biological samples and eject the remaining substances), or extrusion bioprinting (uses temperature-controlled polymerized materials for scaffold fabrication) (60). All these methods combine solid free-form fabrication and precise placement of cells and other biological factors to the desired 2D and 3D positions. This system offers additional biocompatibility and capacity for uniform cell incorporation. It begins with intrinsic organization and offers a template to guide reconstruction of cells and thus create a biomimmicked tissue with high throughput and cell manipulation. Use of personalized tissue substitutes promotes and enhances regeneration in areas of defected tissue (61). This system has shown promise in gene and drug delivery with precise placement during tissue construction. However, compared to HOCs, the limitations of this system include difficulties in managing single cells, over-drying leading to the failure of biological systems, and cell damage and altered phenotype caused by the printing process. Bioprinting requires fine-tuning of matrices for optimal conditions of simulation and deposition of cells and scaffolds. Also the current strategies still cannot fabricate new tissue that is indistinguishable from native tissue in vivo with respect to the zonal organization, ECM composition, and mechanical properties. Introduction of structures in vivo to facilitate organ regeneration have shown that infused cells may fail to maintain their formation in the recipient (61). Thus, the precise delivery of cells and biological factors to the desired 3D cultures is still far from being resolved.

\section{Organoids}

This system stands at the forefront of 3D approaches as it more accurately recapitulates in vivo characteristics of the original individual's tissue because the ECM and cell-cell interactions are intrinsic to the culture. Organoids have been successfully generated from human healthy and diseased tissue and pluripotent stem cells (62). Organoids from primary tissue sustain basement membrane extracts that are hallmarks of the original tissue in terms of architecture, cell type composition, and selfrenewal properties. Patient-specific organoids have allowed functional genomic studies that can be related to the diagnosis of a patient and, with future development, will contribute to the generation of personalized therapies. However, in comparison to HOCs, organoids lack histological diversity and sequential differentiation as occurs in adult human tissue. They also lack surrounding tissue that is important for the interplay of cell-cell and cell-ECM cross talk, requires structural support to promote continuity and proper orientation of cell growth and can be quite heterogeneous from tissue to tissue and fail to generate tissue of origin. For example generation of cerebral organoids that have used embryonic bodies (EBs) kept in suspension leads to uniform neural ectoderm formation along the outer surface of EBs, whereas inner non-neural mesendodermal tissues do not develop, and the neurons do not display a six-layered architecture such as that seen in vivo (63). Cultures are also prone to acquiring independent secondary alterations and can quickly grow beyond the limits of stationary diffusion of oxygen and nutrients. 
Thus, although promising in their application, 3D cultures and organoids have not as yet accurately reflect the characteristics of primary human cells in vivo.

\section{Organ-in-a-Chip}

This emerging $3 \mathrm{D}$ cell-culture model better mimics the microstructure, dynamic mechanical properties, and biochemical functionalities of living organs. It integrates microfluidic devices created with microfabrication techniques (photolithography, replica molding, and microcontact printing) using living cells cultured within 3D devices to study human physiology in an organ-specific context, and to develop specialized in vitro disease models (64). Structures with defined shapes and positions are created by microfabrication techniques on the micrometer scale to position cells and tissues, control cell shape, and function, and create highly structured 3D culture microenvironments. The development of a multi-analytic optical sensing module for dynamic measurements of $\mathrm{pH}$ and dissolved oxygen levels in the culture medium has been recently reported (65). Small amounts of fluids are manipulated in microfabricated hollow channels to generate and precisely tune dynamic fluid flows and spatiotemporal gradients, as well as deliver nutrients and other chemical cues to cells in a controlled manner. However, HOCs retain several advantages over organ-on-a-chip. The latter still remains an artificial model relying on microfabricated scaffolds to mimic ECM, and thus failing to recapitulate in vivo tissue. These systems lack multi-organ interactions that are critical to some aspects of drug metabolism and toxicity. Interrelationship and cross talk between multiple cell types and the dynamics for modulating physiological processes are currently too complex to be recapitulated in such a system. Table 2 summarizes the strengths and weakness of all emerging cell cultures as compared to HOCs.

TABLE 2 | Summary of the strength and weakness of the human organ culture (HOC) with emerging cell cultures.

\begin{tabular}{|c|c|c|}
\hline & Strength & Weakness \\
\hline \multirow[t]{5}{*}{ 2D cell cultures } & Simple model, easy to manipulate, low cost & $\begin{array}{l}\text { A static system of cell growth that does not reflect the situation in vivo. } \\
\text { Lacks cell-cell and cell-extracellular matrix (ECM) interactions }\end{array}$ \\
\hline & $\begin{array}{l}\text { Uniform rich oxygenation. Nutrients are provided to all cells, and } \\
\text { waste products are secreted directly into the media }\end{array}$ & $\begin{array}{l}\text { Growth on plastic flasks/plates affect polarity, morphology and } \\
\text { migratory properties of cells }\end{array}$ \\
\hline & Easy environment to control, allowing manipulation of cells & $\begin{array}{l}\text { Extended passages may alter the phenotype and histological } \\
\text { characteristics of cells }\end{array}$ \\
\hline & Can be used as a platform for drug testing & $\begin{array}{l}\text { Fails to mimic a physiological microenvironment. Inability to depict } \\
\text { traits exhibited using in vivo systems }\end{array}$ \\
\hline & $\begin{array}{l}\text { Can be conveniently observed and analyzed by imaging } \\
\text { techniques }\end{array}$ & \\
\hline
\end{tabular}

Three-dimensional (3D) Recreates cell-cell and cell-ECM contact that mimic the in vivo cell cultures natural environment promoting spatial organization and high

More expensive and time consuming than 2D cultures density culturing

Provides a simple but efficient tool for investigating cellular responses non-invasively and in real time under physiologically relevant conditions

Cells can survive prolonged incubation

Lacks natural stromal architecture and some molecules important for promoting attachment, differentiation and proliferation of cells

Great promise for drug discovery, provides predictive response of ECM scaffolds do not recapitulate the complexity of the in vivo matrix and substrate elasticity can effect cell morphology and function drug activation and safety in organ-specific cells ECM scaffolds may contain biological pathogens and show batchto-batch variability in composition

Show better response to exogenous stimuli and withstands more ECM scaffolds may effect mechanical strain and flow shear stress stress when countered by cytotoxic agents dynamic models

Induces changes more relevant to disease models Vascular networks lack segmental structure

Cell morphology/function may alter in culture, either as a result of passaging before introduction into the scaffold or direct contact with the scaffold

3D Bioprinting Provides material with optimal rheological properties that can restore, maintain, and improve tissue formation Very expensive and technically difficult. Requires fine-tuning for optimal conditions. Different imprinting methods have different limitations Offers additional biocompatibility and capacity for targeted cell incorporation at specific sites Printing process may cause cell damage and alter cell phenotype. Infused cells may not be incorporated

Potential for high throughput when optimal conditions have been Materials can suffer batch-to-batch variation and difficulties with established scale-up

\begin{tabular}{lll}
\hline Organoids & $\begin{array}{l}\text { Retains tissue identity and closely recapitulate 3D structural } \\
\text { organization }\end{array}$ & $\begin{array}{l}\text { Can require scaffolds/polymers to provide structural organization and } \\
\text { promote continuity and proper orientation of cell growth }\end{array}$ \\
& $\begin{array}{l}\text { Amenable to high throughput drug screening; patient-derived } \\
\text { organoids allow 5personalized therapy design }\end{array}$ & $\begin{array}{l}\text { Growth of cells requires careful formulation of media/supplements } \\
\end{array}$
\end{tabular}




\begin{tabular}{|c|c|c|}
\hline & Strength & Weakness \\
\hline & $\begin{array}{l}\text { Can be readily expanded and frozen to create a master } \\
\text { "cell-bank" for subsequent use }\end{array}$ & $\begin{array}{l}\text { Cell growth can be limited by the diffusion of oxygen and nutrients } \\
\text { into the organoids }\end{array}$ \\
\hline & Ability to capture sub-clonal populations in vitro & $\begin{array}{l}\text { Lacks secondary tissue that can be important for the interplay of } \\
\text { cell-cell and cell-ECM cross talk }\end{array}$ \\
\hline & Can generate tissue from pluripotent cells & Can display significant variability between preparations \\
\hline & Can be maintained for more than 1 year in long-term culture & \\
\hline & Serial examination allows developmental study of tissue & \\
\hline \multirow[t]{8}{*}{ Organ-on-a-chip } & $\begin{array}{l}\text { Multifluidic chambers allow for the possibility of tissue/organ } \\
\text { interconnection }\end{array}$ & $\begin{array}{l}\text { Scaffolds used as ECM fails to mimic in vivo architecture and lack } \\
\text { interrelationship and cross talk from multiple cell types }\end{array}$ \\
\hline & Utilizes smaller media volumes than static cultures in wells & $\begin{array}{l}\text { Simplified ECM can lead to matrix degradation or contraction and } \\
\text { may suffer a high batch-to-batch variation }\end{array}$ \\
\hline & $\begin{array}{l}\text { Fluid flow between channels allow prolonged culture periods } \\
\text { than static cultures and facilitates cell growth environment }\end{array}$ & Complex channel designs make it difficult in cell seeding \\
\hline & $\begin{array}{l}\text { Multi-organ system allows assessment of drug efficacy and } \\
\text { toxicity predictions }\end{array}$ & $\begin{array}{l}\text { Relies on a superficial model system to deliver fluids via microfluidic } \\
\text { chambers }\end{array}$ \\
\hline & $\begin{array}{l}\text { Allows high throughput sample processing and more realistic } \\
\text { sample size }\end{array}$ & Variation in tools/scaffold/fluid quantity can affect outcome \\
\hline & $\begin{array}{l}\text { Transparent nature of the fabrication materials makes imaging } \\
\text { simpler }\end{array}$ & $\begin{array}{l}\text { Fabrication process can prove technically challenging, leading } \\
\text { to induction of bubbles and flow perturbations that can destroy } \\
\text { cell cultures }\end{array}$ \\
\hline & & Cell media may influence cell phenotype \\
\hline & & Prolonged cultures reduce tissue viability \\
\hline \multirow[t]{4}{*}{ HOCs } & $\begin{array}{l}\text { Provide cell-cell and cell-ECM interactions in a natural } \\
\text { environment preserving endogenous molecules and growth } \\
\text { factors }\end{array}$ & $\begin{array}{l}\text { Human samples may be difficult to obtain; limitation in sample } \\
\text { numbers may affect experimental design }\end{array}$ \\
\hline & $\begin{array}{l}\text { Preserve the naturally complex stromal architecture, vascular } \\
\text { networks, and parenchymal anatomy facilitating better response } \\
\text { to external signals }\end{array}$ & Tissue viability reduced by prolonged cultures \\
\hline & $\begin{array}{l}\text { Gene/protein expression profiling/imaging can be carried out } \\
\text { on cultures using established tissue assays }\end{array}$ & $\begin{array}{l}\text { Large samples may restrict delivery of oxygen and nutrients and } \\
\text { penetration of exogenous stimuli }\end{array}$ \\
\hline & $\begin{array}{l}\text { Variability in patient-to-patient responses to exogenous stimuli } \\
\text { can be assessed }\end{array}$ & $\begin{array}{l}\text { Real-time monitoring may be limited by the depth of the thickness } \\
\text { of the tissue }\end{array}$ \\
\hline
\end{tabular}

\section{OUTSTANDING QUESTIONS}

In this review, we have summarized how HOCs offer several significant advantages as compared to conventional and newer $3 \mathrm{D}$ cultures for studies of patho-physiologic mechanisms that better reflect the in vivo situation. However, HOCs also have some limitations. Chief among these is tissue acquisition, which results in limited sample size, variability, and heterogeneity. Heterogeneity and variability are problems faced in many human investigation and genetic analyses may help in stratification and lead to classifications into subtypes. In other words, this may be turned into an advantage if sufficient numbers of samples are available. Acquisition will remain a problem but can be partly addressed by an organized and efficient approach to ethical sample collection. Second major challenge is the limited viability of most organ culture systems. In our hands, deterioration in tissue architecture occurs after $18 \mathrm{~h}$ incubation. In general, more extended periods of survival will be needed to allow genetic techniques, such as RNAi-mediated gene knockdown or vector-mediated overexpression to be carried out successfully. Protein transfection using cell-permeating tags on wild-type, constitutively active, or dominant-negative proteins may be used as alternatives. Other problems include uneven penetration or cellular uptake of vectors. Experience with siRNA in organ cultures has shown some success $(46-48,66)$. A third current limitation of HOCs that needs to be addressed is the lack of perfusion leading to metabolic perturbations in the microenvironment. Perfusion itself may influence the system by providing shear stress and pulsations, physical signals especially important for vascular studies. Attempts have been made to address this issue (67), but further advances will be needed to develop a physiological flow system that allows for controlled hemodynamics in HOCs.

\section{CONCLUSION}

In contrast to other experimental cultures commonly employed for basic research or preclinical drug testing in the human system, HOCs offer the advantage of studying tissue cells remaining within their at least partially intact microenvironment. Increasing data demonstrate that cell lines, when kept in culture too long, exhibit reduced or altered key functions and often no longer represent reliable models of their original source material. HOCs preserve the integrity of 
cells and matrices in an organ-specific structure and are more likely to be clinically relevant. The response of a whole integrated tissue to a simple ubiquitous signal will reflect not just the specificity of the signal or the receptor affinity, but also the microenvironment of juxtaposed cell types and ECM. Structural integrity is a major reason for adopting organ culture as an in vitro method instead of cell culture. HOCs can model a wide range of applications that permit many functional and mechanistic studies and provide a simple but informative model in which to study the effects of pharmacological agents, cytokines, and various other mediators in humans.

\section{REFERENCES}

1. Zimmermann M, Lampe J, Lange S, Smirnow I, Konigsrainer A, Hann-von-Weyhern C, et al. Improved reproducibility in preparing precisioncut liver tissue slices. Cytotechnology (2009) 61(3):145-52. doi:10.1007/ s10616-009-9246-4

2. Hougardy BM, Reesink-Peters $\mathrm{N}$, van den Heuvel FA, ten Hoor KA, Hollema $\mathrm{H}$, de Vries EG, et al. A robust ex vivo model for evaluation of induction of apoptosis by rhTRAIL in combination with proteasome inhibitor MG132 in human premalignant cervical explants. Int J Cancer (2008) 123(6):1457-65. doi:10.1002/ijc.23684

3. Stribos EG, Luangmonkong T, Leliveld AM, de Jong IJ, van Son WJ, Hillebrands JL, et al. Precision-cut human kidney slices as a model to elucidate the process of renal fibrosis. Transl Res (2016) 170:8-16.e1. doi:10.1016/j. trsl.2015.11.007

4. De Kanter R, Olinga P, De Jager MH, Merema MT, Meijer DK, Groothius GM. Organ slices as an in vitro test system for drug metabolism in human liver, lung and kidney. Toxicol In Vitro (1999) 13(4-5):737-44. doi:10.1016/S0887-2333(99)00047-8

5. van Geer MA, Kuhlmann KF, Bakker CT, ten Kate FJ, Oude Elferink RP, Bosma PJ. Ex-vivo evaluation of gene therapy vectors in human pancreatic (cancer) tissue slices. World J Gastroenterol (2009) 15(11):1359-66. doi:10.3748/wjg.15.1359

6. Al-Lamki RS, Lu W, Manalo P, Wang J, Warren AY, Tolkovsky AM, et al. Tubular epithelial cells in renal clear cell carcinoma express high RIPK1/3 and show increased susceptibility to TNF receptor 1 -induced necroptosis. Cell Death Dis (2016) 7(6):e2287. doi:10.1038/cddis.2016.184

7. Al-Lamki RS, Lu W, Wang J, Yang J, Sargeant TJ, Wells R, et al. TNF, acting through inducibly expressed TNFR2, drives activation and cell cycle entry of c-Kit+ cardiac stem cells in ischemic heart disease. Stem Cells (2013) 31(9):1881-92. doi:10.1002/stem.1433

8. Al-Lamki RS, Sadler TJ, Wang J, Reid MJ, Warren AY, Movassagh M, et al. Tumor necrosis factor receptor expression and signaling in renal cell carcinoma. Am J Pathol (2010) 177(2):943-54. doi:10.2353/ajpath.2010.091218

9. Al-Lamki RS, Wang J, Vandenabeele P, Bradley JA, Thiru S, Luo D, et al. TNFR1- and TNFR2-mediated signaling pathways in human kidney are cell type-specific and differentially contribute to renal injury. FASEB J (2005) 19(12):1637-45. doi:10.1096/fj.05-3841com

10. Al-Lamki RS, Wang J, Yang J, Burrows N, Maxwell PH, Eisen T, et al. Tumor necrosis factor receptor 2-signaling in CD133-expressing cells in renal clear cell carcinoma. Oncotarget (2016) 7(17):24111-24. doi:10.18632/ oncotarget. 8125

11. Forino M, Torregrossa R, Ceol M, Murer L, Della Vella M, Del Prete D, et al. TGFbetal induces epithelial-mesenchymal transition, but not myofibroblast transdifferentiation of human kidney tubular epithelial cells in primary culture. Int J Exp Pathol (2006) 87(3):197-208. doi:10.1111/j.13652613.2006.00479.x

12. Phanish MK, Wahab NA, Colville-Nash P, Hendry BM, Dockrell ME. The differential role of Smad2 and Smad3 in the regulation of pro-fibrotic TGFbetal responses in human proximal-tubule epithelial cells. Biochem $J$ (2006) 393(Pt 2):601-7. doi:10.1042/BJ20051106

\section{AUTHOR CONTRIBUTIONS}

Outline of the review: RA-L and JP. Wrote the review: RA-L. Edited the text: JB and JP.

\section{FUNDING}

The authors would like to express their gratitude to The National Institute for Health Research (NIHR) Cambridge Biomedical Research Centre (RA-L, JB).
13. Arvilommi AM, Salmi M, Jalkanen S. Organ-selective regulation of vascular adhesion protein-1 expression in man. Eur J Immunol (1997) 27(7):1794-800. doi:10.1002/eji.1830270730

14. Salmi M, Jalkanen S. Different forms of human vascular adhesion protein-1 (VAP-1) in blood vessels in vivo and in cultured endothelial cells: implications for lymphocyte-endothelial cell adhesion models. Eur JImmunol (1995) 25(10):2803-12. doi:10.1002/eji.1830251014

15. Buchsbaum ME, Kupper TS, Murphy GF. Differential induction of intercellular adhesion molecule-1 in human skin by recombinant cytokines. J Cutan Pathol (1993) 20(1):21-7. doi:10.1111/j.1600-0560.1993.tb01244.x

16. Dustin ML, Singer KH, Tuck DT, Springer TA. Adhesion of T lymphoblasts to epidermal keratinocytes is regulated by interferon gamma and is mediated by intercellular adhesion molecule 1 (ICAM-1). J Exp Med (1988) 167(4): 1323-40. doi:10.1084/jem.167.4.1323

17. Khan IU, Boehm KD, Elmets CA. Modulation of interferon-gammainduced HLA-DR expression on the human keratinocyte cell line SCC-13 by ultraviolet radiation. Photochem Photobiol (1993) 57(2):285-90. doi:10.1111/ j.1751-1097.1993.tb02288.x

18. Han YP, Tuan TL, Hughes M, Wu H, Garner WL. Transforming growth factor-beta- and tumor necrosis factor-alpha-mediated induction and proteolytic activation of MMP-9 in human skin. J Biol Chem (2001) 276(25): 22341-50. doi:10.1074/jbc.M010839200

19. Fajardo LF, Kwan HH, Kowalski J, Prionas SD, Allison AC. Dual role of tumor necrosis factor-alpha in angiogenesis. Am J Pathol (1992) 140(3):539-44.

20. Maguire JJ, Jones KL, Kuc RE, Clarke MC, Bennett MR, Davenport AP. The CCR5 chemokine receptor mediates vasoconstriction and stimulates intimal hyperplasia in human vessels in vitro. Cardiovasc Res (2014) 101(3): 513-21. doi:10.1093/cvr/cvt333

21. Hayes IM, Jordan NJ, Towers S, Smith G, Paterson JR, Earnshaw JJ, et al. Human vascular smooth muscle cells express receptors for CC chemokines. Arterioscler Thromb Vasc Biol (1998) 18(3):397-403. doi:10.1161/01. ATV.18.3.397

22. Messadi DV, Pober JS, Fiers W, Gimbrone MA Jr, Murphy GF. Induction of an activation antigen on postcapillary venular endothelium in human skin organ culture. J Immunol (1987) 139(5):1557-62.

23. Cotran RS, Gimbrone MA Jr, Bevilacqua MP, Mendrick DL, Pober JS. Induction and detection of a human endothelial activation antigen in vivo. J Exp Med (1986) 164(2):661-6. doi:10.1084/jem.164.2.661

24. Liu M, Kluger MS, D’Alessio A, Garcia-Cardena G, Pober JS. Regulation of arterial-venous differences in tumor necrosis factor responsiveness of endothelial cells by anatomic context. Am J Pathol (2008) 172(4):1088-99. doi:10.2353/ajpath.2008.070603

25. Nanney LB, Stoscheck CM, King LE Jr, Underwood RA, Holbrook KA. Immunolocalization of epidermal growth factor receptors in normal developing human skin. J Invest Dermatol (1990) 94(6):742-8. doi:10.1111/ 1523-1747.ep12874601

26. Nanney LB, Stoscheck CM, Magid M, King LE Jr. Altered [125I]epidermal growth factor binding and receptor distribution in psoriasis. J Invest Dermatol (1986) 86(3):260-5. doi:10.1111/1523-1747.ep12285389

27. Valyi-Nagy I, Jensen PJ, Albelda SM, Rodeck U. Cytokine-induced expression of transforming growth factor-alpha and the epidermal growth factor 
receptor in neonatal skin explants. J Invest Dermatol (1992) 99(3):350-6. doi:10.1111/1523-1747.ep12616672

28. Krueger JG, Krane JF, Carter DM, Gottlieb AB. Role of growth factors, cytokines, and their receptors in the pathogenesis of psoriasis. J Invest Dermatol (1990) 94(6 Suppl):135S-40S. doi:10.1111/1523-1747.ep12876121

29. Nickoloff BJ, Mitra RS, Elder JT, Fisher GJ, Voorhees JJ. Decreased growth inhibition by recombinant gamma interferon is associated with increased transforming growth factor-alpha production in keratinocytes cultured from psoriatic lesions. Br J Dermatol (1989) 121(2):161-74. doi:10.1111/j. 1365-2133.1989.tb01795.x

30. Forsberg S, Rollman O. Re-epithelialization from human skin explant cultures is promoted by ligand-activated HER3 receptor. J Dermatol Sci (2010) 59(1):7-15. doi:10.1016/j.jdermsci.2010.03.017

31. Petzelbauer P, Pober JS, Keh A, Braverman IM. Inducibility and expression of microvascular endothelial adhesion molecules in lesional, perilesional, and uninvolved skin of psoriatic patients. J Invest Dermatol (1994) 103(3):300-5. doi:10.1111/1523-1747.ep12394720

32. Pagnini C, Martorelli M, Lanini C, Delle Fave G. Development of an ex vivo organ culture technique to evaluate probiotic utilization in IBD. J Clin Gastroenterol (2016) 50(2):S179-82. doi:10.1097/MCG.0000000000000698

33. Kebouchi M, Galia W, Genay M, Soligot C, Lecomte X, Awussi AA, et al. Implication of sortase-dependent proteins of Streptococcus thermophilus in adhesion to human intestinal epithelial cell lines and bile salt tolerance. Appl Microbiol Biotechnol (2016) 100(8):3667-79. doi:10.1007/s00253-016$7322-1$

34. Das JK, Mahapatra RK, Patro S, Goswami C, Suar M. Lactobacillus acidophilus binds to MUC3 component of cultured intestinal epithelial cells with highest affinity. FEMS Microbiol Lett (2016) 363(8). doi:10.1093/femsle/fnw050

35. Hope TA, Herfkens RJ, Denianke KS, LeBoit PE, Hung YY, Weil E. Nephrogenic systemic fibrosis in patients with chronic kidney disease who received gadopentetate dimeglumine. Invest Radiol (2009) 44(3):135-9. doi:10.1097/RLI.0b013e31819343ba

36. DaSilva M, O’Brien Deming M, Fligiel SE, Dame MK, Johnson KJ, Swartz RD, et al. Responses of human skin in organ culture and human skin fibroblasts to a gadolinium-based MRI contrast agent: comparison of skin from patients with end-stage renal disease and skin from healthy subjects. Invest Radiol (2010) 45(11):733-9. doi:10.1097/RLI.0b013e3181e9436b

37. Sadarangani A, Kato S, Espinoza N, Lange S, Llados C, Espinosa M, et al. TRAIL mediates apoptosis in cancerous but not normal primary cultured cells of the human reproductive tract. Apoptosis (2007) 12(1):73-85. doi:10.1007/s10495-006-0492-z

38. Nitsch R, Bechmann I, Deisz RA, Haas D, Lehmann TN, Wendling U, et al. Human brain-cell death induced by tumour-necrosis-factor-related apoptosisinducing ligand (TRAIL). Lancet (2000) 356(9232):827-8. doi:10.1016/ S0140-6736(00)02659-3

39. Dame MK, Bhagavathula N, Mankey C, DaSilva M, Paruchuri T, Aslam MN, et al. Human colon tissue in organ culture: preservation of normal and neoplastic characteristics. In Vitro Cell Dev Biol Anim (2010) 46(2):114-22. doi:10.1007/s11626-009-9247-9

40. Bhagavathula N, Hanosh AW, Nerusu KC, Appelman H, Chakrabarty S, Varani J. Regulation of E-cadherin and beta-catenin by $\mathrm{Ca} 2+$ in colon carcinoma is dependent on calcium-sensing receptor expression and function. Int J Cancer (2007) 121(7):1455-62. doi:10.1002/ijc.22858

41. Merrick AF, Shewring LD, Sawyer GJ, Gustafsson KT, Fabre JW. Comparison of adenovirus gene transfer to vascular endothelial cells in cell culture, organ culture, and in vivo. Transplantation (1996) 62(8):1085-9. doi:10.1097/00007890-199610270-00011

42. Kunicher N, Tzur T, Amar D, Chaouat M, Yaacov B, Panet A. Characterization of factors that determine lentiviral vector tropism in skin tissue using an ex vivo model. J Gene Med (2011) 13(4):209-20. doi:10.1002/jgm.1554

43. Liu H, Tuchinda P, Fishelevich R, Harberts E, Gaspari AA. Human in vitro skin organ culture as a model system for evaluating DNA repair. J Dermatol Sci (2014) 74(3):236-41. doi:10.1016/j.jdermsci.2014.02.003

44. Burns RP Jr, Ferbel B, Tomai M, Miller R, Gaspari AA. The imidazoquinolines, imiquimod and R-848, induce functional, but not phenotypic, maturation of human epidermal Langerhans' cells. Clin Immunol (2000) 94(1):13-23. doi:10.1006/clim.1999.4804

45. Hague A, Hicks DJ, Hasan F, Smartt H, Cohen GM, Paraskeva C, et al. Increased sensitivity to TRAIL-induced apoptosis occurs during the adenoma to carcinoma transition of colorectal carcinogenesis. Br J Cancer (2005) 92(4):736-42. doi:10.1038/sj.bjc.6602387

46. Baczyk D, Drewlo S, Proctor L, Dunk C, Lye S, Kingdom J. Glial cell missing-1 transcription factor is required for the differentiation of the human trophoblast. Cell Death Differ (2009) 16(5):719-27. doi:10.1038/cdd.2009.1

47. Piazza O, Russo I, Bocchicchio S, Barba AA, Lamberti G, Zeppa P, et al. Cyclin D1 Gene Silencing by siRNA in ex vivo human tissue cultures. Curr Drug Deliv (2017) 14:246-52. doi:10.2174/1567201813666160512150710

48. Talati PG, Gu L, Ellsworth EM, Girondo MA, Trerotola M, Hoang DT, et al. Jak2-Stat5a/b signaling induces epithelial-to-mesenchymal transition and stem-like cell properties in prostate cancer. Am J Pathol (2015) 185(9):2505-22. doi:10.1016/j.ajpath.2015.04.026

49. Ibrahim J, Hughes AD, Sever PS. Action of angiotensin II on DNA synthesis by human saphenous vein in organ culture. Hypertension (2000) 36(5):917-21. doi:10.1161/01.HYP.36.5.917

50. Hafizi S, Chester AH, Allen SP, Morgan K, Yacoub MH. Growth response of human coronary smooth muscle cells to angiotensin II and influence of angiotensin AT1 receptor blockade. Coron Artery Dis (1998) 9(4):167-75. doi:10.1097/00019501-199809040-00001

51. Patel MK, Betteridge LJ, Hughes AD, Clunn GF, Schachter M, Shaw RJ, et al. Effect of angiotension II on the expression of the early growth response gene c-fos and DNA synthesis in human vascular smooth muscle cells. J Hypertens (1996) 14(3):341-7. doi:10.1097/00004872-19960300000011

52. Pampaloni F, Reynaud EG, Stelzer EH. The third dimension bridges the gap between cell culture and live tissue. Nat Rev Mol Cell Biol (2007) 8(10):839-45. doi: $10.1038 / \mathrm{nrm} 2236$

53. Gorain B, Tekade M, Kesharwani P, Iyer AK, Kalia K, Tekade RK. The use of nanoscaffolds and dendrimers in tissue engineering. Drug Discov Today (2017) 22(4):652-64. doi:10.1016/j.drudis.2016.12.007

54. Gurski LA, Jha AK, Zhang C, Jia X, Farach-Carson MC. Hyaluronic acidbased hydrogels as 3D matrices for in vitro evaluation of chemotherapeutic drugs using poorly adherent prostate cancer cells. Biomaterials (2009) 30(30):6076-85. doi:10.1016/j.biomaterials.2009.07.054

55. Htwe SS, Harrington H, Knox A, Rose F, Aylott J, Haycock JW, et al. Investigating NF-kappaB signaling in lung fibroblasts in $2 \mathrm{D}$ and $3 \mathrm{D}$ culture systems. Respir Res (2015) 16:144. doi:10.1186/s12931-015-0302-7

56. Fong AH, Romero-Lopez M, Heylman CM, Keating M, Tran D, Sobrino A, et al. Three-dimensional adult cardiac extracellular matrix promotes maturation of human induced pluripotent stem cell-derived cardiomyocytes. Tissue Eng Part A (2016) 22(15-16):1016-25. doi:10.1089/ten. TEA.2016.0027

57. Luca AC, Mersch S, Deenen R, Schmidt S, Messner I, Schafer KL, et al. Impact of the 3D microenvironment on phenotype, gene expression, and EGFR inhibition of colorectal cancer cell lines. PLoS One (2013) 8(3): e59689. doi:10.1371/journal.pone.0059689

58. Butler CR, Hynds RE, Crowley C, Gowers KH, Partington L, Hamilton NJ, et al. Vacuum-assisted decellularization: an accelerated protocol to generate tissue-engineered human tracheal scaffolds. Biomaterials (2017) 124:95-105. doi:10.1016/j.biomaterials.2017.02.001

59. Lee JM, Mhawech-Fauceglia P, Lee N, Parsanian LC, Lin YG, Gayther SA, et al. A three-dimensional microenvironment alters protein expression and chemosensitivity of epithelial ovarian cancer cells in vitro. Lab Invest (2013) 93(5):528-42. doi:10.1038/labinvest.2013.41

60. Zhu W, Ma X, Gou M, Mei D, Zhang K, Chen S. 3D printing of functional biomaterials for tissue engineering. Curr Opin Biotechnol (2016) 40:103-12. doi:10.1016/j.copbio.2016.03.014

61. Langer R, Vacanti JP. Tissue engineering. Science (1993) 260(5110):920-6. doi:10.1126/science.8493529

62. Bredenoord AL, Clevers H, Knoblich JA. Human tissues in a dish: the research and ethical implications of organoid technology. Science (2017) 355(6322). doi:10.1126/science.aaf9414

63. Lancaster MA, Renner M, Martin CA, Wenzel D, Bicknell LS, Hurles ME, et al. Cerebral organoids model human brain development and microcephaly. Nature (2013) 501(7467):373-9. doi:10.1038/nature12517

64. Huh D, Hamilton GA, Ingber DE. From 3D cell culture to organs-onchips. Trends Cell Biol (2011) 21(12):745-54. doi:10.1016/j.tcb.2011.09.005

65. Mousavi Shaegh SA, De Ferrari F, Zhang YS, Nabavinia M, Binth Mohammad N, Ryan J, et al. A microfluidic optical platform for real-time monitoring of 
$\mathrm{pH}$ and oxygen in microfluidic bioreactors and organ-on-chip devices. Biomicrofluidics (2016) 10(4):044111. doi:10.1063/1.4955155

66. Davies JA, Ladomery M, Hohenstein P, Michael L, Shafe A, Spraggon L, et al. Development of an siRNA-based method for repressing specific genes in renal organ culture and its use to show that the Wt1 tumour suppressor is required for nephron differentiation. Hum Mol Genet (2004) 13(2):235-46. doi:10.1093/hmg/ddh015

67. Miyakawa AA, Dallan LA, Lacchini S, Borin TF, Krieger JE. Human saphenous vein organ culture under controlled hemodynamic conditions. Clinics (Sao Paulo) (2008) 63(5):683-8. doi:10.1590/S1807-59322008000500018
Conflict of Interest Statement: The authors declare that the research was conducted in the absence of any commercial or financial relationships that could be construed as a potential conflict of interest.

Copyright (c) 2017 Al-Lamki, Bradley and Pober. This is an open-access article distributed under the terms of the Creative Commons Attribution License (CC BY). The use, distribution or reproduction in other forums is permitted, provided the original author(s) or licensor are credited and that the original publication in this journal is cited, in accordance with accepted academic practice. No use, distribution or reproduction is permitted which does not comply with these terms. 